\title{
Assessing the Economical Efficiency of Intermodal Chains in Global Trade
}

\author{
Bogusz Wiśnicki ${ }^{1, *}$ and Dariusz Milewski ${ }^{2}$ \\ ${ }^{1}$ Transport Engineering and Economics Faculty, Maritime University of Szczecin, Waly Chrobrego 1- \\ 2, 70-500 Szczecin, Poland \\ ${ }^{2}$ Faculty of Management and Economics of Services, University of Szczecin, Cukrowa 8, 70-001 \\ Szczecin, Poland
}

\begin{abstract}
The paper relates to the development of intermodal technologies used in international trade, together with factors which will influence that development at present and in the future. The aim of the paper is to assess impact of the integration of intermodal chains on logistics costs and thus on global trade. The special emphasize is laid on the problem of the diversity of standards of containers and transport technology in different parts of the world. This research is based on the available statistical data and information obtained from leading logistics operators. The authors conducted comparative analysis of the economic efficiency of usage of different sizes of cargo units, both standard and nonstandard, relating to representative intermodal chain between the USA and Europe. In order to assess different scenarios a model was elaborated for calculating the total costs of such a chain, and transport efficiency analysis with the use of this model were conducted. The results of research presented in the paper confirm that integration of intermodal chains thanks to standardization of loading units in a global scale could be profitable. The results of logistics cost analysis prove measurable benefits for logistics operators and as well as their customers.
\end{abstract}

\section{Introduction}

In order to draw a comparison between present state and technological development prospects of intermodal transport, one should start with differences in understanding of the notion of intermodal transport on a global scale. The main two areas of development and the standardisation of intermodal transport to Europe and the United States. Hence, these are the basic areas of further research in the context of this publication.

In Europe a point of reference is the definition of Economic Commission for Europe (UN/ECE), which says that intermodal transport is "the movement of goods in one and the same loading unit or road vehicle, which uses successively two or more modes of transport without handling the goods themselves in changing modes" [1]. In the USA the following explanation of the Intermodal Association of North America (IANA) which is commonly used: "Intermodal transport - the movement of freight, in a container or on a trailer, by

\footnotetext{
* Corresponding author: b.wisnicki@am.szczecin.pl
} 
more than one mode of transportation; the movement can be made from rail to truck to ship in any order". The difference in the phrase ,without handling the goods themselves" brings about consequences in transport technologies used on both continents. In the USA so-called container transloading, which is rare in Europe, is a common practice. It consists in dismantling loading units in order to set up new, differently sized container units. This situation takes place in sea ports where the cargo is loaded from ISO maritime containers (20' and 40') to larger domestic 53' containers. The most important advantages of transloading are: a possibility of sorting out loading batches in the port, and the use of a smaller number of containers in activities between the port and the hinterland (three 40' containers can correspond to two 53' container).

Among many differences between the intermodal transport in the EU and USA the most important ones from the viewpoint of a further analysis are as follows:

- fewer infrastructure limitations in the USA make it possible to implement cost-efficient technologies in rail (longer trains, heavier railcars, double stack loads) and road transport (longer road trains);

- a considerable difference in transport organization which is affected by greater liberalization of the market in the USA as well as conditions of tough competition in the EU often depending on factors beyond the market;

- the EU is characterized by a much denser network of terminals belonging to different operators and short-distance transits;

- the use of transport technologies typical for continents, that is Ro-La in the EU and bimodal modes in the USA

- transloading in the USA which has broken the European definition of intermodal transport;

- ports play their major role in both cases in port-to-door distribution, but in the USA longdistance landbridges and trade corridors are typical, whereas in Europe there is rather a network of intermodal corridors with mixed logistic solutions.

By analysing the generic structure of intermodal units in the USA, it can be stated that according to the IANA data from the year 2014, 50\% of the carried units were ISO containers, $40 \% 53^{\prime}$ 'domestic containers, and $10 \%$ share belonged to semitrailers. The available statistical data from 2011 about Europe show an important participation of 50\% ISO containers, $42 \%$ of swap bodies, $8 \%$ share of road trains and $3 \%$ share of semitrailers (fig. 1). A 50\% share of containers which handle cargo on sea routes is common for both markets. A kind of counterpart for swap bodies which are used in the continental transport are 53 'containers in the USA. Both types of transport units are domestic standards and as such are better adapted to the market needs of the two analysed continents.

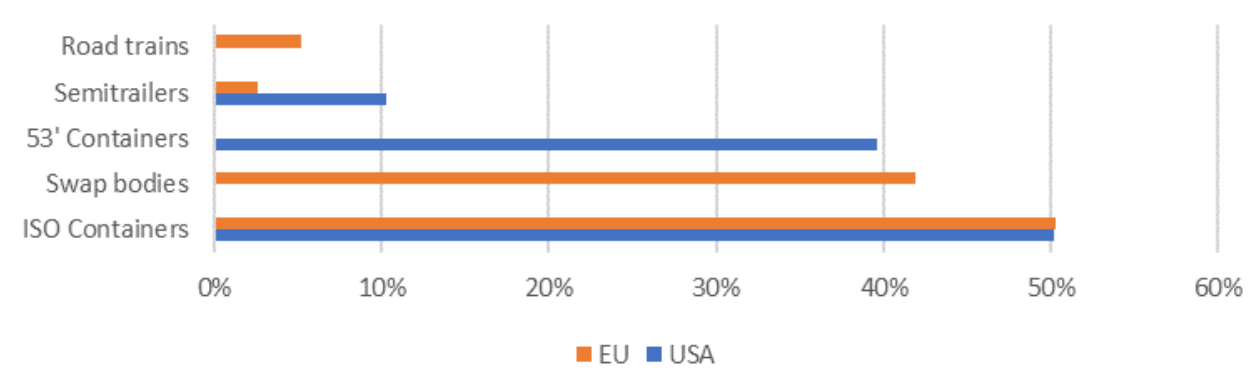

Fig. 1. Structure of ITU in Europe and USA according to transport volume.

Source: [2] and UIRR Reports (www.uirr.com), 2012 and IANA Statistics (intermodal.org). 
The phenomenon of economies of scale and associated cost advantages is common in any business. In transport lower unit costs can be obtained due to greater performance of transport operations measured by distance and volume. The loading capacities of transport type and transport equipment have been increasing for many years. In some regions of the world the global standards are being extended through the introduction of the use of larger domestic transport units. In the USA, large intermodal loading units are widely used, including containers 53', which are not a worldwide ISO standard. Interestingly, the use of such units on a local market is inconsistent with the idea of technological integration of the door-to-door supply chains and involves additional manipulations. Despite this, it is costefficient. This shows that the aforementioned phenomenon of scale actually occurs in this case, so one could assume that the cost efficiency would be even higher if such larger units were used on the whole door-to-door route.

The authors' intention was to examine under what conditions the admission of containers larger than 40' (45' and 53') in the transport links between the United States and Europe could be economically viable. The aim is to assess impact of the integration of intermodal chains on logistics costs and thus on global trade. To realize this purpose the authors used a cost model of a transport chain. With the help of this model economic calculations of proposed solutions were made for a number of examples of different sizes of containers and different intercontinental transport links.

\section{Literature review}

The problems of the usage of intermodal technology are quite often described in the literature - both in scientific and the professional publications. Topics presented refer to a wide range of issues: optimization of intermodal chains, the choice of transport technologies, the transport services market and transport policy [3]. The mafjority of research concerns transport links between the EU and the Far East. It is much more difficult to find studies relating to the transport between the USA and Europe. This is understandable, as the turnover between the two continents is much smaller than with China.

One of the most important problems connected with intermodal transport is its economical efficiency measured primarily by its costs. The share of investment costs is very high and, according to some authors, can even reach $50 \%$ of the total intermodal terminal cost [4]. Although the cost of intermodal transport and structure of these costs are given in different ways in different publications [5-8], we can agree that the share of fixed costs is relatively higher and requires a high efficiency of operations resulting from utilization of transport types, their capacity and scale of operations.

The efficiency of one process usually depends not only on the performance of that process but also others connected with it. Transport and logistics are very good examples of such system effects, because the transport and logistics processes are strongly interrelated. Some authors point to organizational matters, strategy and the relations between transport technology with other logistics processes such as warehousing [9], allocation of resources in an intermodal terminal or the assignment of trucks and the fleet size in intermodal drayage operations [10]. These relations can be conditions for achieving economies of scale and they can be found in the maritime intermodal transport. Big container ships allow economies of scale, but economies of container ship operations are dependent on port productivity. Hence, there are also disadvantages of scale and there is often an optimum scale by which the benefits are maximal. The same problem refers to the whole logistics chain (understood here as being wider than the pure transport chain), in which striving for economies of scale in transport can result in higher costs for other logistics processes. Numerous models have been developed to prove that such relations actually exist [11]. 
Many transport models have been developed to allow decision-making processes [12]. Among these there are also many intermodal transport models, which relate to a wide range of issues such as operational and organizational problems [13], the optimal level of investment $[14,15]$ and the market for transport services and transport policy [16].

Models presented in the literature have been designed in many cases to solve specific problems in individual parts of the intermodal chain. An example of such a model is the PLATFORM Model [17]. Another problem concerns optimization criteria, which are sometimes of a non-economic character. There are models that take into account the system approach and even cover an entire intermodal chain. An example of such a model is the Heuristics Intermodal Transport Model (HIT-model) [18, 19]. But there is a lack of information of the verification of these models in scientific publications. Another problem linked with these is a too high level of aggregation, and data which are quite often averaged. It should be noted, however, that if economic criteria are used in a model this means that external costs are also being taken into account [20].

So far, the most developed model for calculating total costs of a planned intermodal connection is that made by Janic [21]. Three types of costs were included in his model: the internal costs - borne by transport operators, the time costs of goods tied in transit and the external costs - the costs of the impacts on society and the environment. The model concerns the problem of choice of a transport solution for the transport of containerised cargo, i.e. for cargo which comes through sea ports.

None of the existing models presented in the literature concern the problem of the different sizes of intermodal units in different regions. None can be directly used for analysis of containerized supply chains in which goods are reloaded from one cargo unit to another. The authors in the present study undertook this research challenge by adapting for this research the above-mentioned model of Janic.

\section{Research methodology}

The purpose of this research was to assess the cost-efficiency of the use of various sizes of container transport units carried in sea-land intermodal chains. The authors conducted a comparative analysis of the economic efficiency of the transport chain using cargo units of different sizes, including standard and non-standard. For assessing different scenarios of transport, the mathematical model was elaborated and calculations with the use of this model were conducted. The obtained results were used for the assessment of the influence of the use of different combinations of containers on the economic efficiency of global trade by comparing the costs of deliveries of goods with the value of these goods.

The model reflects the economic trade-off relation between the costs of handling and the carriage costs. The decision problem occurs when there is non-integrated intermodal transport forced by differences in standards in transport infrastructure or means of transport. As a result, in the supply chain the differences in standards dictate a change in the means of transport or loading unit. Such a change from a smaller unit to a bigger one can allow a reduction of total costs if savings in transport costs offset increased transloading costs.

The construction of the proposed calculation model is based on the Janic's model [21] and is presented as a mathematical formula, enabling a calculation of the total cost of the transport chain (tab. 1). The total costs include four components: transport (carriage) costs, time costs, handling costs, external costs. Carriage costs are prices paid by transport users. 
Table 1. Mathematical formula for calculating total costs of an intermodal chain

Carriage cost

$$
C_{I / k}=\sum_{i=1}^{n} F r_{I / k / i} \times N_{T U / k / i}
$$

Handling costs

$$
C_{H / k}=\sum_{i=1}^{n} H r_{k / i} \times N_{T U / k / i}
$$

Transport External costs

$$
C_{E / k}=\sum_{i=1}^{n} Q_{k} \times d_{k / i} \times c_{E / k / i}
$$

Total costs

$$
C_{F U L L / k}=C_{I / k}+C_{T / k}+C_{H / k}+C_{E / k}
$$

$F r_{I / k / i}$ - transport freight rate per unit per leg

$N_{T U / k / i}$ - number of transport units on a transportation leg

$Q_{k}$ - total weight of a cargo

$H r_{k / i}$ - handling rate for transhipment (including transloading) a transport unit

$d_{k / i}$ - number of km of a transport leg

$c_{E / k / i}$ - unit external costs of a transport mode

Source: Authors' calculations.

Such a model could be used as a tool for making decisions concerning the choice of type and size of containers used in an analysed transport chain. The model could also provide the base for wider macroeconomic calculations and thus could be useful for policy makers. Firstly, because various technologies affect external costs. Secondly, because the integration of the various technologies would probably require investment, e.g. roads.

The transport relations chosen for this study are sea-land connections between the USA and Europe. This choice stems from the fact that in the supply chains between these regions different cargo units are used, including standard sea containers as well as domestic units. What is important, in some cases transloading container-to-container operations are observed, which an unusual procedure for integrated intermodal transport is.

It is not possible at this stage of research to put forward a concrete hypothesis because in order to provide proof extensive research would be needed. Therefore, the authors conducted here only limited calculations with the use of the developed model.

\section{Analysis of the economic efficiency of the use of large containers in US-Europe intermodal transport}

With the use of the presented above model a simulation of economical efficiency of the international trade with the use of big containers has been conducted. The calculations were made for the following variants transportation of cargo from the USA to Europe:

- transportation of container 40 'on the entire route,

- transport of container 53 'to the port in the US and transloading of goods to container 40',

- transport of 45 ' containers on the entire route,

- transport of 53 'containers to the port in the US and transloading of goods to container 45',

- transportation of 53 'containers on the entire route. 
The model considers the transport and handling costs at land terminals and seaports, which vary depending on the length of land routes, the total cargo weight to be transported, cargo density, freight and transload rates. In a case of a change of a transportation unit during transport, a transloading fee is additionally charged. The capacity of containers depends on their technical capabilities (tonnage, volume in $\mathrm{m} 3$ and the number of pallets) and the permissible payloads for road transport in different countries. The limitations are regulations in the countries with the lowest permissible gross weight (36 tons in the USA).

Data used in the simulation are presented in tables 2-3. Transport rates are estimated based on freight tables of transport operators in the USA and Europe.

Table 2. Capacity of containers in USA and EU

\begin{tabular}{cccc}
\hline Container size & $\begin{array}{c}\mathbf{4 0} \text { ' pallet } \\
\text { wide }\end{array}$ & $\begin{array}{c}\mathbf{4 5}^{\prime} \text { pallet } \\
\text { wide }\end{array}$ & $\begin{array}{c}\mathbf{5 3} \text { ' pallet } \\
\text { wide }\end{array}$ \\
\hline Number of europallets (two layers) & 60 & 66 & 80 \\
Space [m3] & 79 & 89,2 & 112 \\
Tare weight [t] & 15,8 & 16,3 & 17,1 \\
Netto weight on road EU [t] & 28,2 & 27,7 & 26,9 \\
Netto weight on road USA [t] & 20,2 & 19,7 & 18,9 \\
Netto weight on rail or inland transport [t] & 31 & 32 & 34 \\
Weight limit EU [t] & 44 & 44 & 44 \\
Weight limit USA [t] & 36 & 36 & 36 \\
\hline
\end{tabular}

Source: Authors' calculations based on market data and regulations.

Table 3. Freight rates for $40^{\prime}$ on individual sections of the door-to-door route

\begin{tabular}{|c|c|c|c|c|c|c|c|c|c|}
\hline \multirow{3}{*}{$\begin{array}{l}\text { Dist. } \\
\text { road } \\
{[\mathrm{km}]}\end{array}$} & \multicolumn{4}{|c|}{ USA } & \multirow{3}{*}{$\begin{array}{c}\text { Port } \\
\text { rate } \\
{[\$ / \text { cont. }]}\end{array}$} & \multirow{3}{*}{$\begin{array}{c}\begin{array}{c}\text { Sea } \\
\text { voyage }\end{array} \\
{[\$ / \text { cont. }} \\
]\end{array}$} & \multicolumn{3}{|c|}{$\mathbf{E U}$} \\
\hline & $\begin{array}{l}\text { Road } \\
\text { rate }\end{array}$ & $\begin{array}{l}\text { Terminal } \\
\text { rate }\end{array}$ & $\begin{array}{l}\text { Rail } \\
\text { dist. }\end{array}$ & $\begin{array}{l}\text { Rail } \\
\text { rate }\end{array}$ & & & $\begin{array}{l}\text { Port } \\
\text { rate }\end{array}$ & $\begin{array}{c}\text { Land } \\
\text { distance }\end{array}$ & $\begin{array}{l}\text { Intermo } \\
\text { dal rate }\end{array}$ \\
\hline & $\begin{array}{c}{[\$ / \text { con }} \\
\text { t. }]\end{array}$ & [\$/cont.] & {$[\mathrm{km}]$} & $\begin{array}{c}{[\$ / \text { con }} \\
\text { t.] }\end{array}$ & & & [\$/cont.] & {$[\mathrm{km}]$} & [\$/cont.] \\
\hline 10 & 40 & 324 & 450 & 800 & & & & 200 & 220 \\
\hline 110 & 100 & 324 & 600 & 900 & & & & 300 & 300 \\
\hline 210 & 150 & 324 & 750 & 1000 & & & & 400 & 370 \\
\hline 310 & 200 & 324 & 900 & 1100 & & & & 500 & 440 \\
\hline 410 & 230 & 324 & 1050 & 1200 & 203 & 2130 & 203 & 600 & 480 \\
\hline 510 & 250 & 324 & 1200 & 1250 & 293 & 2130 & 293 & 700 & 515 \\
\hline 610 & 260 & 324 & 1350 & 1280 & & & & 800 & 550 \\
\hline 710 & 265 & 324 & 1500 & 1300 & & & & 900 & 570 \\
\hline 810 & 270 & 324 & 1650 & 1350 & & & & 1000 & 590 \\
\hline 910 & 280 & 324 & 1800 & 1400 & & & & 1100 & 600 \\
\hline
\end{tabular}

Source: Authors' calculations based on freight rates of transport operators: worldfreightrates.com and imtis.contargo.net.

One of the most important factors is the density of a cargo. Hence, the calculations were carried out for various cargo density options assuming that the total load weight is 200 tons (tab. 4). Containers 53' are the most efficient for lighter cargo of density up to $0,25 \mathrm{t} / \mathrm{m} 3$. For heavier goods option 53'-45' is the best option, what confirms high efficiency of the 53', which are profitable even, when they are not used on the whole route and an additional transloading takes place. 
Table 4. Impact of a cargo density of a commodity on internal costs of a delivery

\begin{tabular}{cccccc}
$\begin{array}{c}\text { Cargo Density } \\
{[\mathrm{t} / \mathrm{m} 3]}\end{array}$ & $40^{\prime}-40^{\prime}$ & \multicolumn{2}{c}{ Combination of containers } \\
\hline 0,10 & 179600 & $53^{\prime}-40^{\prime}$ & $45^{\prime}-45^{\prime}$ & $53^{\prime}-45^{\prime}$ & $53^{\prime}-53^{\prime}$ \\
0,21 & 89800 & 86800 & 157589 & 154085 & 132677 \\
0,25 & 78575 & 77161 & 78794 & 77042 & 66338 \\
0,36 & 56125 & 62727 & 57783 & 68223 & 60810 \\
0,50 & 56125 & 59119 & 57783 & 55429 & 60810 \\
0,63 & 56125 & 59119 & 57783 & 55429 & 60810 \\
0,80 & 56125 & 59119 & 57783 & 55429 & 60810 \\
0,89 & 56125 & 59119 & 57783 & 55429 & 60810 \\
1,13 & 56125 & 59119 & 57783 & 55429 & 60810 \\
1,33 & 56125 & 59119 & 57783 & 55429 & 60810 \\
\hline
\end{tabular}

Note: Calculations are made for the following scenario: distance on land legs $-3810 \mathrm{~km}$, total weight of delivery $-200 \mathrm{t}$, difference in freight rates $-45^{\prime} / 40$ ' increase $103 \%, 53^{\prime} / 40^{\prime}$ increase $110 \%$.

Source: Authors' calculations.

The next simulation concerned the impact of differences between rates for transporting containers, assuming the increase for larger containers in comparison to standard 40' unit. Option 53 '-53 'is the cheapest one, provided that the freight rates for these containers will not be 50\% higher than $40^{\prime}$ (tab. 5). Option $45^{\prime}-45^{\prime}$ is more profitable from option $40^{\prime}-40^{\prime}$ when freight rates for $45^{\prime}$ containers are not higher by $24 \%$ compared to 40 'container rates.

Table 5. Impact of diversification of rates on internal costs of the delivery

\begin{tabular}{|c|c|c|c|c|c|c|}
\hline \multicolumn{2}{|c|}{ Average changes of rates } & \multicolumn{5}{|c|}{ Combination of containers } \\
\hline $45^{\prime} / 40^{\prime}$ & $53^{\prime} / 40^{\prime}$ & $40^{\prime}-40^{\prime}$ & $53^{\prime}-40^{\prime}$ & $45^{\prime}-45^{\prime}$ & $53^{\prime}-45^{\prime}$ & $53^{\prime}-53^{\prime}$ \\
\hline $3 \%$ & $10 \%$ & 179600 & 173600 & 157589 & 154085 & 132677 \\
\hline $6 \%$ & $20 \%$ & 179600 & 177632 & 161128 & 160144 & 142114 \\
\hline $9 \%$ & $30 \%$ & 179600 & 181664 & 164666 & 166202 & 151550 \\
\hline $12 \%$ & $40 \%$ & 179600 & 185696 & 168205 & 172261 & 160987 \\
\hline $15 \%$ & $50 \%$ & 179600 & 189728 & 171744 & 178320 & 170424 \\
\hline $18 \%$ & $60 \%$ & 179600 & 193760 & 175283 & 184379 & 179861 \\
\hline $21 \%$ & $70 \%$ & 179600 & 197792 & 178822 & 190438 & 189298 \\
\hline $24 \%$ & $80 \%$ & 179600 & 201824 & 182360 & 196496 & 198734 \\
\hline $27 \%$ & $90 \%$ & 179600 & 205856 & 185899 & 202555 & 208171 \\
\hline $30 \%$ & $100 \%$ & 179600 & 209888 & 189438 & 208614 & 217608 \\
\hline
\end{tabular}

Source: Authors' calculations.

The benefits of the analysed combinations for two factors: load density and the increase in freight rates. Large containers are relatively very profitable for transporting loads with a density of $0.10 \mathrm{t} / \mathrm{m} 3$ and $0.21 \mathrm{t} / \mathrm{m} 3$, even with considerable increases in freight rates. With heavier loads of density from $0.25 \mathrm{t} / \mathrm{m} 3$, there is a significant drop in efficiency, and the differences in freight rates have a big influence.

The model has also been used to estimate the possible benefits of using larger containers in the entire USA-Europe trade. Not only the costs of the delivery were analysed, but also costs of purchase. Based on previously presented data on trade in goods between the USA and the EU it can be estimated that the average weight of cargo carried in containers is 7.1 $\mathrm{t} / \mathrm{TEU}$ (based on Eurostat). This corresponds to the load density of $0.25 \mathrm{t} / \mathrm{m} 3$. Assuming also that transport costs together with transport insurance amount to $15 \%$ of the value of the goods [22], it was assumed that value of a cargo is $600 \$ / \mathrm{t}$. Assuming also that the total turnover between the US and the EU is 109 million tons, simulations have been carried out for $1 \%$ of this potential turnover. 
Simulation results showing possible cost savings in percentage terms, including additional external costs, are presented in table 6 . External costs slightly, i.e. by $3 \%-4 \%$, increase the total costs, which can be explained by the fact that the analysis assumed the use of rail transport in the USA and only the inland waterway in the EU to a large extent. These branches, especially sea transport (the longest segment) generate relatively the lowest external costs. The simulation proved that the biggest savings relate to the 53'-53' combination and increase with distance.

Table 6. Total costs of procurement of goods (incl. external costs)

\begin{tabular}{cccccc}
\hline $\begin{array}{c}\text { Total land } \\
\text { distance } \\
{[\mathbf{k m}]}\end{array}$ & $40^{\prime}-40^{\prime}$ & $53^{\prime}-40^{\prime}$ & $45^{\prime}-45^{\prime}$ & $53^{\prime}-45^{\prime}$ & $53^{\prime}-53^{\prime}$ \\
\hline 660 & $0,0 \%$ & $0,0 \%$ & $-3,3 \%$ & $-2,7 \%$ & $-6,9 \%$ \\
1010 & $1,9 \%$ & $-0,2 \%$ & $-3,9 \%$ & $-3,4 \%$ & $-7,5 \%$ \\
1360 & $3,6 \%$ & $-0,4 \%$ & $-4,4 \%$ & $-4,0 \%$ & $-8,0 \%$ \\
1710 & $5,4 \%$ & $-0,6 \%$ & $-4,9 \%$ & $-4,6 \%$ & $-8,6 \%$ \\
2060 & $6,7 \%$ & $-0,7 \%$ & $-5,1 \%$ & $-5,0 \%$ & $-8,9 \%$ \\
2410 & $7,6 \%$ & $-0,8 \%$ & $-5,4 \%$ & $-5,3 \%$ & $-9,2 \%$ \\
2760 & $8,3 \%$ & $-0,9 \%$ & $-5,6 \%$ & $-5,6 \%$ & $-9,4 \%$ \\
3110 & $8,8 \%$ & $-0,9 \%$ & $-5,7 \%$ & $-5,7 \%$ & $-9,6 \%$ \\
3460 & $9,5 \%$ & $-1,0 \%$ & $-5,9 \%$ & $-5,9 \%$ & $-9,7 \%$ \\
3810 & $10,1 \%$ & $-1,1 \%$ & $-5,9 \%$ & $-6,0 \%$ & $-9,8 \%$ \\
\hline
\end{tabular}

Note: Calculations are made for the following scenario: cargo density $-0,25 \mathrm{t} / \mathrm{m} 3$, total weight of delivery $-10900 \mathrm{t} /$ year, total value of delivery $-6540 \mathrm{~m} \$$ /year, difference in freight rates $-45^{\prime} / 40^{\prime}$ increase $103 \%, 53^{\prime} / 40$ ' increase $110 \%$.

Source: Authors' calculations.

\section{Conclusions}

The results of research presented in the paper confirm that integration of intermodal chains thanks to standardization of loading units in a global scale could be profitable. The results of logistics cost analysis prove measurable benefits for logistics operators and as well as their customers. The important factor of integration of intermodal chains is a unification and increasing the dimensions of loading units, what in turn will allow reduce logistics costs and accelerate global trade.

The conducted analysis relating to representative intermodal chain between the USA and Europe allows to conclude that the use of 53' or 45' containers instead of standard 40' units in door-to-door relation could have an impact on lowering the cost of trade between America and Europe. However, it should be noticed that introduction of larger units needs to overcome some important technological limitations, both on maritime section (construction of containerships) and in the land infrastructure in Europe. The authors are of an opinion that it is in American and European interest to overcome this barrier.

The following phenomena and processes which take place in the global trade allow the use of the above conclusions in the world scale, taking into account the specifics of each transport relationship:

- there is a great potential of the containerization development;

- more and more light and very light commodities are carried in containers which tend to be transported in larger loading units;

- transport of large containers, i.e. 45' and 53', by the water and rail means of transport does not require significant changes in law, but only design (construction) adjustment. 
The calculations have been made with an aim to use the most credible data sources and avoid approximate data. Therefore, the authors' aim was to avoid subjectivism. It is advisable to conduct further research based on a thorough analysis and extender models. Authors postulate extension the scope of economic analysis of intermodal global chains considering other factors of their costs. Further research should identify the relations between logistics costs and volume of global trade.

\section{References}

1. UN ECE, Terminology on Combined Transport, www.unece.org, (2001)

2. UIC Report, Report on Combined Transport in Europe, International Union of Railways - UIC, Paris, (2012)

3. D. Milewski, B. Wisnicki, Modelling intermodal transport systems - directions for scientific research, Research Journal of the University of Gdańsk Transport Economics and Logistics, Vol. 66, 35-42 (2017)

4. A. Ballis, J. Golias, Towards the improvement of a combined transport chain performance, European Journal of Operational Research, 152, 420-436, (2003)

5. J. Wronka, Transport intermodalny/kombinowany - teoria i praktyka, Wydawnictwo Naukowe Uniwersytetu Szczecińskiego, Szczecin 2008, 114, (2008)

6. S. Dărăbanț, P. Ștefănescu, R. Crișan, Economic benefits of developing intermodal transport in the European Union, Annals of the University of Oradea, Economic Science Series, Vol. 21, Issue 2, 81-87, (2012)

7. J. Stokłosa, Š. Liščák, M. Jaśkiewicz, K. Ludwinek, Systemy transportu intermodalnego - kierunki rozwoju w świetle europejskich doświadczeń, Logistyka, 6, 10070-10074, (2014)

8. K. Liljestrand, Intermodal transportation from a haulier's perspective. An analysis on how to increase the usage of intermodal road-rail transportation for hauliers in Sweden, Chalmers University of Technology. Göteborg, Sweden, Report No. E., (2010)

9. B. Guszczak, Intermodal transport as an attractive mode of transport, Research in Logistics and Production, 4(3), 209-219, (2014)

10. A. Caris, C. Macharis, G.K. Janssens, Planning Problems in Intermodal Freight Transport: Accomplishments and Prospects, Transportation Planning and Technology, 31(3), 277-302, (2008)

11. K.Baumgartnera, A. Fuettererb, U.W. Thonemannb, Supply chain design considering economies of scale and transport frequencies, European Journal of Operational Research, 218(3), 789-800, (2012).

12. G. Jong de, I. Vierth, L. Tavasszy, M. Ben-Akiva, Recent developments in national and international freight transport models within Europe, Transportation,. 40, s. 347-371, (2013)

13. L.M.Gambardella, M. Mastrolilli, A.E. Riz Zoli, M. Zaffalon, An optimization methodology for intermodal terminal management, Journal of Intelligent Manufacturing, 2001, Vol. 12, No. 5/6, 521-534, (2000) 
14. M.B. Pedersen, Optimization models and solution methods for intermodal transportation, PhD thesis. Centre for Traffic and Transport Technical University of Denmark, 171, (2005)

15. E. Kozan, Optimising container transfers at multimodal terminals, Mathematical and Computer Modelling, Vol. 31, 235-243, (2000)

16. C.Macharis, E. Van Hoeck, E. Pekin., T. Van Lier, A decision analysis framework for intermodal transport: comparing fuel price increases and the internalization of external costs, Transportation Research, Part A 44, 550-561, (2010)

17. A.E. Rizzoli, N. Fornara, L.M. Gambardella, A simulation tool for combined rail/road transport in intermodal terminals, Mathematics and Computers in Simulation, No. 59, 57-71, (2002)

18. J. Flodén, Modelling Intermodal Freight Transport - The Potential of Combined Transport in Sweden, Department of Business Administration. Gøteborg University, (2007)

19. B. Groothedde, C.Ruijgrok, L. Tavasszy, Towards collaborative, intermodal hub networks. A case study in the fast moving consumer goods market, Transportation Research Part E: Logistics and Transportation Review, 41, 567583, (2005)

20. B. Sahin, H. Yilmaz, Y. Ust, A.F. Guneri, B. Gulsun, E. Turan, An Approach for Economic Analysis of Intermodal Transportation, The Scientific World Journal, 10 p., (2014)

21. M. Janic, Modelling the full costs of an intermodal and road freight transport network, Transportation Research D, 12(1), 33-44, (2007)

22. UNCTAD Review of Maritime Transport 2017, UNCTAD/RMT/2017, United Nations Publication, 55, (2017) 